\title{
Differentiation of Mediterranean species of Juniperus from the Sabina section as a result of their migrations
}

\author{
Małgorzata Mazur*
}

\section{Article info}

Received: 8 Mar. 2021

Revision received: 23 Jul. 2021

Accepted: 23 Jul. 2021

Published: 31 Dec. 2021

\section{Associate Editor}

Elżbieta Cieślak

\begin{abstract}
The Sabina section is one of the three groups in the Juniperus genus and the most diverse. The variability of Mediterranean junipers from the Sabina section is related to their Tertiary and Pleistocene migrations and long-term isolations. Their contemporary taxonomic and geographic diversity was influenced by important events such as the migration of continents, the disappearance of Tethys, orogenic movements or the Messinian salinity crisis. The results of morphological measurements of seed cones, seeds and branchlets with leaves of 19 populations of Juniperus phoenicea complex, J. excelsa s.str., J. thurifera subsp. thurifera and subs. africana, J. foetidissima and J. sabina var. sabina and var. balkanensis were statistically compiled using univariate statistics and multivariate analysis. The most important characters differentiating the populations within the taxa were the thickness of the branchlet and the cone diameter, while between the taxa the ratio of cone diameter to the width of the seeds and the number of seeds per cone were used for speciation. J. phoenicea complex is distinguished from the other studied taxa by the greatest number of characters. J. foetidissima, J. sabina var. sabina and J. canariensis are characterized by the highest variability of morphological characters, while J. excelsa and J. sabina var. balkanensis - the lowest. The studies confirmed the ancient nature of the $J$. phoenicea complex in relation to other taxa from the Sabina section, as a result of an earlier detachment from the ancestor, and no loss of variability due to the effects of colonization and isolation in J. canariensis. In addition, the similarity of $J$. sabina and $J$. thurifera was demonstrated, which would confirm the descent from a common ancestor and similar migration routes from the center of Europe towards the Iberian Peninsula, as well as further differentiation of $J$. thurifera into subspecies caused by isolation due to the opening of the Strait of Gibraltar. The distinctiveness of $J$. foetidissima from all the other analyzed taxa was also confirmed, and some morphological similarity was shown, proving the original character of $J$. excelsa s.str. and its similarity to the $J$. phoenicea complex in this respect.
\end{abstract}

Key words: biogeography, biometry, Cupressaceae, plant morphology, plant variation

\section{Introduction}

Juniperus is the second most diverse genus of all the coniferous plants and the largest of the 30 members of the Cupressaceae family. It includes about 75 species (Farjon 2005; Adams 2014) of evergreen trees and shrubs of different heights and habitats (Zohary 1973; Browicz 1982; Adams 2014). The Juniperus and Cupressus genera and the Hesperocyparis-Callitropis-Xanthocyparis clade come from a common ancestor more than 60 million years ago, most likely from Asia, and the divergence of Juniperus and Cupressus was about 56 million years ago (Mao et al. 2019). The development of Mediterranean vegetation was associated with the displacement of continental plates and

Department of Evolutionary Biology, Kazimierz Wielki University, Ossolińskich 12, 85-093 Bydgoszcz, Poland

ORCID: 0000-0003-0043-3706

*Corresponding author e-mail: mazur@ukw.edu.pl the disappearance of Tethys (Popov et al. 2006; Ivanov et al. 2011). The diversification of the genus Juniperus started probably during the Eocene, in the Tethyan belt of vegetation in Eurasia, and further spread and evolution in Europe, Asia, Africa, and North America took place in the Oligocene, and the early Neogene, due to geological events that started with the collision of Arabia with Eurasia (Allen \& Armstrong 2008). This event was accompanied by marine regressions and transgressions, orogeny and climate change, which caused, among other events, the creation of the Mediterranean Sea (Popov et al. 2006; Ivanov et al. 2011). The emergence of arid habitats with low rainfall were less suitable to other species (Axelrod 1975; Willis \& McElwain 2002; Farjon 2005; Mao et al. 2010), thus resulting in more or less intense speciation processes in isolated lines of the genus (Mao et al. 2010). The closure of the Strait of Gibraltar and the Messinian 
salinity crisis in the Miocene (about 5.3 million years ago) allowed for further migration and exchange of flora between Europe, Africa and Asia (Bocquet et al. 1978; Verdu et al. 2003; Kovar-Eder et al. 2006; Favre et al. 2007). The history of the Juniperus was further influenced by the Pliocene climate cooling, Pleistocene cyclic glaciations, as well as human activities in recent centuries and competition with other species (Jimenez et al. 2003). High requirements for access to light and a pioneering nature make it easier for junipers to colonize new areas. Additionally, there are arbuscular mycorrhizal fungi, typical for dry and semi-dry areas (Sanguin et al. 2016), which may help them survive (Salvà-Cotarineu et al. 2021). For the Juniperus from the Iberian Peninsula and the Balkans, based on the pollen stratigraphy, spreading has been shown during the dry periods of the Late Pleistocene and Holocene and withdrawal in wetter periods, mainly due to competition with broadleaf trees (Carrión et al. 2001a, b, 2003, 2004, 2010; Tzedakis 2004). Migrations caused by climate change and often large distances created in this way between parts of the range of individual species, led to further differentiation. Long-term variability between populations at the molecular level may lead to the emergence of lower-rank taxa within the species, also identified by phenotypic characters. In several cases, the emergence of geographically isolated varieties, subspecies, and even species was confirmed, e.g., in the cases of $J$. thurifera s.lat. (Boratyński et al. 2013) and J. phoenicea s.lat. (Mazur et al. 2010, 2018; Romo et al. 2019).

The habitat requirements of junipers are the cause of small amounts of their preserved remains, because the dry habitats they choose do not favor the formation of macrofossils (Kvaček 2002). Moreover, in palynological studies, juniper pollen is identified only at the genus level (Carrión et al. 2003). Thus, the history of the evolution of junipers and possible migration routes or periods of isolation of species and populations in refuges can only be traced by studying their current molecular, morphological, and geographical diversity (Bennet et al. 1991; Petit et al. 2003).

The existence of three main Juniperus differentiation centers is presumed: the Mediterranean region, the desert of Mexico with the southwestern part of USA and central Asia (western China), while geographic distribution is mainly limited by climate, biotic interactions and dispersal ability (Mao et al. 2010; Adams 2014; Salvà-Cotarineu et al. 2021). It is assumed that the processes of hybridization and speciation still take place within the taxon, which increase its diversity (Farjon 2005; Mao et al. 2010, 2019; Adams 2014).

The genus Juniperus has been divided into three monophyletic sections: Caryocedrus (only one species J. drupacea in the Mediterranean region), Juniperus (syn: Oxycedrus Spach; 14 species in Mediterranean, East Asia, and one the circumboreal - J. communis) and Sabina (Miller) Spach (approx. 60 species in the Mediterranean, Asia, Africa and southwestern North America) (Farjon 2005; Adams 2014). Sabina is the least homogeneous of all sections and is divided into three or four groups (Mao et al. 2010; Adams \& Schwarzbach 2013; Adams
2014), two of them with entire leaves: single-seeded junipers with turbinate cones of eastern hemisphere and multi-seeded of the eastern and western hemispheres (e.g.: J. excelsa, J. foetidissima, J. thurifera and J. sabina) and the next two groups with serrate leaves: junipers of North America and multi-seeded junipers with only slightly serrate leaves (treated as 'pseudoserrate') of the eastern hemisphere (J. phoenicea, J. turbinata and J. canariensis), which is the reason why the latter are included in the multi-seeded group with entire leaves.

The ancestor of the Sabina section was most likely from Asia (Mao et al. 2010). During the Eocene and the Oligocene, Sabina were widespread in the Madrean-Tethyan vegetation belts on three continents (Axelrod 1975; Wen \& Ickert-Bond 2009; Adams 2014; Wen et al. 2016). The earliest Sabina divergence event probably took place in Central or Central and Western Europe, in the Oligocene, with the appearance of a multi-seeded juniper with slightly serrate leaves (J. phoenicea complex) (Mao et al. 2010). It is assumed that the ancestor of J. phoenicea s.lat. was part of the Tethian-Madrean flora (Axelrod 1975) and subsequently migrated to both American continents, then became the ancestor of a group of American serrated-leaved junipers (Adams \& Schwarzbach 2013; Mao et al. 2019). The species included in the multi-seeded junipers with entire leaves, J. excelsa, J. foetidissima, $J$. thurifera and J. sabina, are believed to originate from the same ancestor and their differentiation may have occurred at the end of the Tertiary due to the cooling of the climate (Barbero et al. 1994; Jiménez et al. 2003; Marcysiak et al. 2007). As already suggested by Barbero and co-workers (1994) based on biometric and biochemical studies by $J$. excelsa and $J$. thurifera, the likely migration route during the Tertiary, from the central European ancestor, was two phyletic lines: through the submountain Alps regions to the Iberian Peninsula along the route northwest leading to the uprising of $J$. thurifera and to the northeast Balkans, which led to the creation of $J$. excelsa. Such migration pathways have been confirmed by $J$. thurifera molecular tests (Jiménez et al. 2003) and in the leaf oil comparisons (Adams et al. 2003). The isolation and survival of glacials in different refuges should have led to further differentiation between these species (Hewitt 1996, 1999, 2004).

Currently, the ranges of $J$. excelsa s.str. and J. foetidissima overlap, while the range of $J$. thurifera is isolated. The typical $J$. excelsa is a mountain taxon, which can create forests locally and occurs in southeastern Europe and southwestern Asia at elevations of 500-1500 m. It can also occur at lower altitudes of about 50-100 m, for example in the Crimea (Browicz 1982; Boratyński et al. 1992; Didukh 1992). J. foetidissima grows in areas similar to the typical $J$. excelsa and can sometimes be found together, growing in the mountains of the Eastern Mediterranean, in Europe and Asia, often on rocks or rocky slopes, from a Mediterranean to more continental climate (Browicz 1982; Boratyński et al. 1992; Farjon 2005; Adams 2014). J. thurifera grows in the mountains in the western part of the Mediterranean Region, in the Iberian Peninsula, French Alps and Corsica, in West 
Europe and Atlas and Anti-Atlas in North Africa (Farjon 2005; Romo \& Boratyński 2005; Boratyński et al. 2013). $J$. foetidissima is distinguished from typical $J$. excelsa and $J$. thurifera by a smaller number of seeds, larger seeds and thicker shoots with leaves (Farjon 2005; Marcysiak et al. 2007; Adams 2014). The distinctiveness of $J$. foetidissima is probably also partly due to its mountainous character and occurrence in higher altitudes, which limited its range and deepened the distance to the co-occurring J. excelsa (Browicz 1982; Boratyński et al. 1992; Didukh 1992; Farjon 2005; Marcysiak et al. 2007).

The distinction between taxa within the $J$. excelsa group is debatable. Two subspecies were assumed: $J$. excelsa subsp. excelsa and $J$. excelsa subsp. polycarpos, where the typical Greek juniper is characterized by slightly thinner twigs, smaller seed cones, and more seeds (Farjon 2005) and occurs in the western part of the range in a Mediterranean climate - in the Balkan Peninsula, Anatolia, Syria, Lebanon, Iran, and Crimea (Jalas \& Suominen 1973; Browicz 1982; Boratynński et al. 1992; Farjon 2005; Douaihy et al. 2012). Latest research, mainly Adams and co-workers, based on leaf essential oils, RAPD, isoenzyme analysis, nrDNA and cpDNA assume the existence of the $J$. excelsa complex, which includes $J$. excelsa, J. polycarpos with two varieties (var. polycarpos and var. turcomanica) and J. seravschanica (Adams 2014, 2016; Hojjati et al. 2009, 2019).

The Juniperus sabina group is widely distributed from Spain, through Europe to Kazakhstan, Siberia, Mongolia, and China (Farjon 2005). In the isolated eastern part of the range, different contents of leaf terpenoids were noted (Adams et al. 2006a). Similar differences were shown by RAPD analyses (Adams et al. 2007) and, consequently, after further analyses of nrDNA and cpDNA, this part of the range is referred to as a separate taxon $J$. davurica, which have distinguished into varieties (Adams \& Schwarzbach 2013). The typical taxon is characteristic of mountainous areas and its discontinuous range extending from the east of Mongolia to the Iberian Peninsula to the west (Browicz \& Zieliński 1982; Farjon 2005; Zając \& Zając 2009; Adams 2014). Adams and co-workers (2016) described a new variety, J. sabina var. balkanensis R. P. Adams et A. N. Tashev, from the Balkan Peninsulas (Bulgaria and Greece). Subsequent studies showed the presence of 'balkanensis' variety in western Turkey (Adams et al. 2017), Bosnia-Herzegovina, Italy, Croatia, Macedonia (Adams et al. 2018a) and Albania (Adams et al. 2018b). The new variety is reported as a trace of the old hybridization between the two species $J$. sabina var. sabina and $J$. thurifera, and differs from the typical one in having $J$. thurifera-like chloroplasts, but it is difficult to distinguish morphologically. Studies of 29 populations of $J$. sabina, including 13 var. sabina and 16 var. balkanensis, showed that all studied populations of 'balkanensis' are tetraploid, while 'sabina' are diploid (Farhat et al. 2019). The current geographic distribution of these three taxa does not coincide and $J$. thurifera does not occur in the Balkans (Farjon 2005; Romo \& Boratyński 2005; Boratyński et al. 2013). Most likely the ranges of taxa or the ranges of their ancestors were wider (Terrab et al. 2008; Mao et al. 2010), so it is possible that their geographical ranges coincided in the past (Farhat et al. 2019), while hybridization could have occurred during the Oligocen-Miocen migration of $J$. thurifera and $J$. sabina from the center of its creation to the Iberian Peninsula (Jimenez et al. 2003; Marcysiak et al. 2007). Cases of J. sabina var. balkanensis and $J$. thurifera occurring together in the French Alps have been documented (Farhat et al. 2020). Examination of several individuals with atypical morphology revealed allotriploid cases resulting from the hybridization between the tetraploid of $J$. thurifera and the diploid of J. sabina. The authors suggest that incomplete reproductive barriers may be enabling interspecies hybridization and even genetic introgression through further backcrossing.

Juniperus phoenicea complex now has a wide range, covering the entire Mediterranean region - from the Canary Islands, Atlas Mountains, and the Atlantic coast of Portugal in the west, through southern Europe, southwest Asia, to Jordan, Saudi Arabia, and Israel in the east, mainly growing in the sphere of influence mild Mediterranean climate, but also continental, e.g., in the Atlas Mountains (Jalas \& Suominen 1973; Quezel \& Pesson 1980; Browicz 1982; Boratyński et al. 1992; Charco 2001; Farjon 2005). Genetic research on the complex revealed inconsistent relationships between regions and migration history (Adams et al. 2002, 2006b, 2010, 2013; Meloni et al. 2006; Boratyński et al. 2009; Dzialuk et al. 2011). The latest genetic and biometric studies covering phenotypic characters did not reveal clear geographic trends, but confirmed the taxonomic distinctiveness of J. phoenicea s.str. and J. turbinata (Pinna et al. 2014; Jimenez et al. 2017; Mazur et al. 2018; Sanchez-Gomez et al. 2018) and gave rise to the distinction of the third species in the complex: J. canariensis (Romo et al. 2019). The history of the migration of the complex, after separating from its ancestor in the Oligocene, was indicated by Lebreton \& Thivend (1981) and Lebreton \& Rivera (1989). They conducted research on the content of procyanidins and prodelfinidines in leaves and showed its origin from the Iberian Peninsula. Contemporary geographical ranges of these three species, due to the choice of a different ecological niche, evolved as a result of isolation and adapting to local conditions (Salvà-Cotarineu et al. 2021). J. phoenicea s.str. is characterized by a narrower range than $J$. turbinata. It occurs inland, mainly in dolomite soils, in submountain and mountain positions in the Iberian Peninsula, southern France, and northwest Italy. It is a pioneering species, in various types of forest and shrub communities, adapted to the Mediterranean climate. It occurs in a wide range of bioclimates, from humid to semi-arid habitats, but also in a temperate climate on mountain slopes (Arrigoni 2012; Mazur et al. 2016; Salvà-Cotarineu et al. 2021). J. turbinata has a much wider range and may be found covering sandy coastal soils in regions around the Mediterranean Sea, colonizing sand dunes and rocks, and in the mountains of northwest Africa and southwest Asia, occurring up to 2,400 $\mathrm{m}$ in the High Atlas, creating open scrubland or forests. However, it most often grows up to $400 \mathrm{~m}$ above sea level, mainly 
in the semi-arid to humid Mediterranean climate (Browicz \& Zieliński 1982; Boratyński et al. 1992; Adams 2014; Mazur et al. 2016). Due to the relatively wide range of occurrence, the species shows great diversity. The most important, but not taxonomically significant, as in the case of $J$. oxycedrus (Boratyński et al. 2014), was noted between African and European populations, which confirms the importance of the Strait of Gibraltar. Slightly lower differentiation was found between European and Asian populations, which may be related to the intercontinental barrier in the form of the Aegean Sea, which was found to be more significant in the case of $J$. drupacea (Sobierajska et al. 2016). J. canariensis can be found in the Canary Islands, except the two driest islands of Lanzarote and Fuenteventura, and in isolated specimens in Madeira. It grows in an oceanic climate, where it forms patches, penetrating into shrub communities, at an altitude of up to 1,000 m (Fernández-Palacios et al. 2008; Romo \& Salvà-Catarineu 2013; Adams 2014; Romo et al. 2019; Salvà-Cotarineu et al. 2021). Interestingly, J. canariensis has not shown a loss of genetic diversity due to the bottleneck or foundational effects during the colonization of Canary Islands, neither at the genetic level (Jimenez et al. 2017; Sanchez-Gomez et al. 2018) nor at the morphological level (Mazur et al. 2018).

The aim of this study was to trace the history of evolution and presumed migration routes of Mediterranean species of Juniperus from the Sabina section based on available published data and to check to what extent their taxonomic and geographical diversity, especially supported by genetic and biochemical research, is reflected in the morphology of cones, seeds, and shoots.

\section{Materials and methods}

Plant material

Material from biometric measurements of 19 populations of Juniperus foetidissima, J. thurifera subsp. thurifera, J. thurifera subsp. africana, J. excelsa s.str., J. phoenicea, J. turbinata, J. canariensis, J. sabina var. sabina and $J$. sabina var. balkanensis, analyzed for specific taxa groups in several previous studies (including three populations of $J$. sabina not yet published; see Table 1), has been re-analyzed. The aforementioned taxa have been thoroughly tested, but separately and on a different set of morphological characters of cones, seeds, and shoots. In this study, the output data from the measurements were analyzed statistically together and based on characters that proved important in distinguishing species. This made it possible to compare the morphological variability of characters both within and between taxa, which allowed for obtaining additional information to know the history of the migration and evolution of the Sabina section in the Mediterranean region.

Every population was represented by $14-36$ individuals, 445 in total, and every individual by 10 cones and 10 one-year-old lateral branchlets. The set of 15 morphological characters of cones, seeds, and branchlets with leaves (Table 2) and measurement procedures of three new populations used for this study were taken from earlier studies (Marcysiak et al. 2007; Mazur et al. 2018).

\section{Statistical treatment}

The unimodality and frequency distribution of each character was checked by the Shapiro-Wilk test. The discontinuous and quality character: the number of cone scale rows, which takes two values in Juniperus, section Sabina: 4 for decussate or 6 for ternete cones, was converted into the percentage of cones with 4 scale rows (CSR4). Before starting multivariate analyses the arcsine transformation was applied, in accordance with the procedure used earlier (Mazur et al. 2018). The homogeneity of variance was verified by Levene's test (Zar 1999; Sokal \& Rohlf 2003). The correlation between 15 characters was checked with the Pearson's linear correlation coefficient to assess potential redundancy (Pearson 1900). Data were standardized to avoid possible effects of different types of characters used in the study. The arithmetic means, standard deviations, and variation coefficients of characters were calculated for each population and taxon. The influence of all characters on the differentiation of populations and taxa were verified using Tukey's T-test (Zar 1999). The taxonomic distance between nine taxa was pre-tested by the cluster analysis (Cattell 1943; Sokal \& Rohlf 2003) and illustrated on the UPGMA dendrogram constructed on the Euclidean distances (Zar 1999). The results were verified using the discriminant function (McLachlan 2004), which allowed us to check the discriminatory power of each character and to verify the relationships between populations and detect the geographic patterns of differentiation within taxa. The dispersions of individuals from populations between the first two discriminant variables were shown on a scatterplot. All calculations were made using STATISTICA 13 (TIBCO Software Inc. 2017).

\section{Results}

The frequency distribution of the values of studied characters was unimodal and normal or close to in most populations and the variances were homoscedastic for most characters. The standardization of data improved obtaining these assumptions.

The values of the variation coefficient (VC) for most characters oscillate between $5.8 \%$ (the number of cone scales - CSN in J. thurifera subsp. africana) to $45.2 \%$ (the ratio SN/CSN for J. foetidissima). However, the VC values of two characters, the percent of decussate type of cones (CSR4) and the ratio describing the shape of seed cones $(\mathrm{CL} / \mathrm{CD})$, were very specific. The character $\mathrm{CL} / \mathrm{CD}$ had a very low $\mathrm{VC}$ value, ranging from $2.1 \%$ (J. phoenicea) to $6.6 \%$ (J. turbinata). The VC value in all populations averaged $3.6 \%$. The second character, CSR4, averaged $11.1 \%$ in all populations ranged between $0.0 \%$ (J. thurifera and J. sabina) and $56.8 \%$ (J. canariensis). The most variable characters for all analyzed taxa turned out to be those related to the number of seeds: SN/CSN, $\mathrm{SN}$, and $\mathrm{CD} / \mathrm{SN}$, characterized by the average value of 

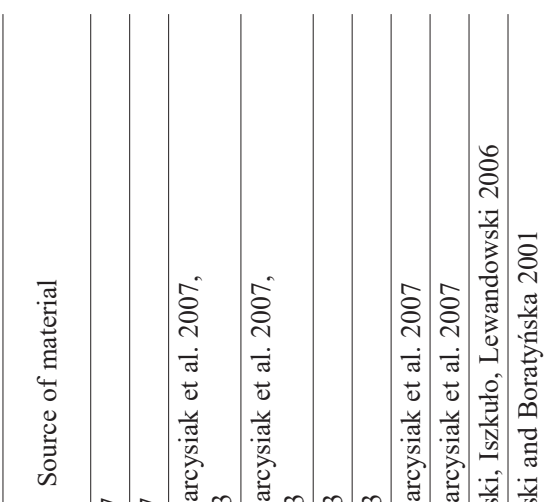

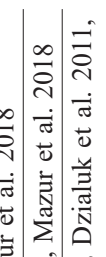

齐

$\frac{0}{2} \geq 4$

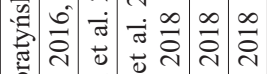

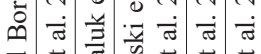

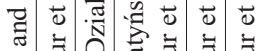

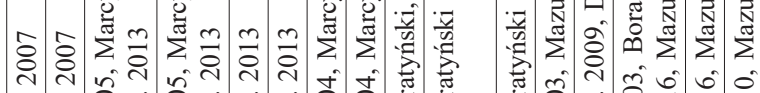

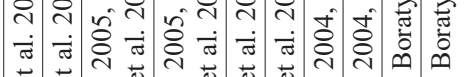

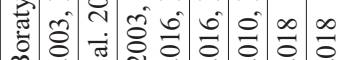

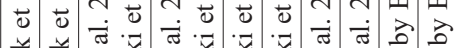

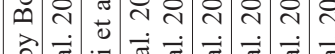

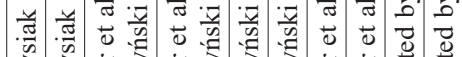

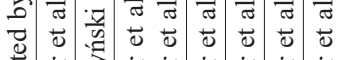

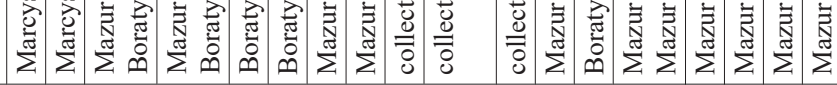

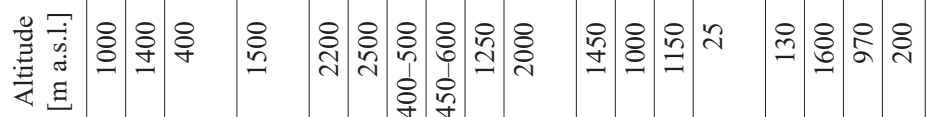

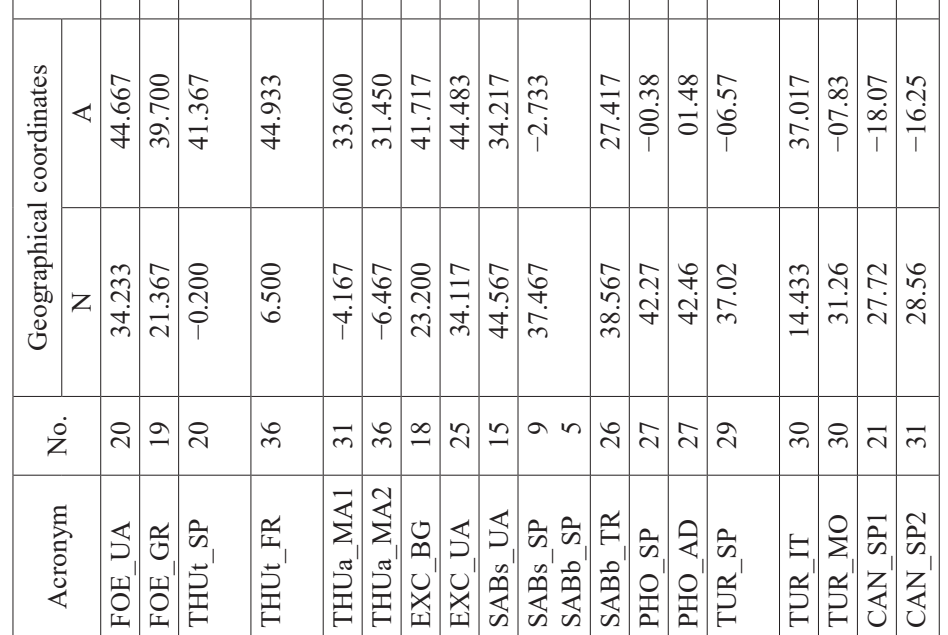

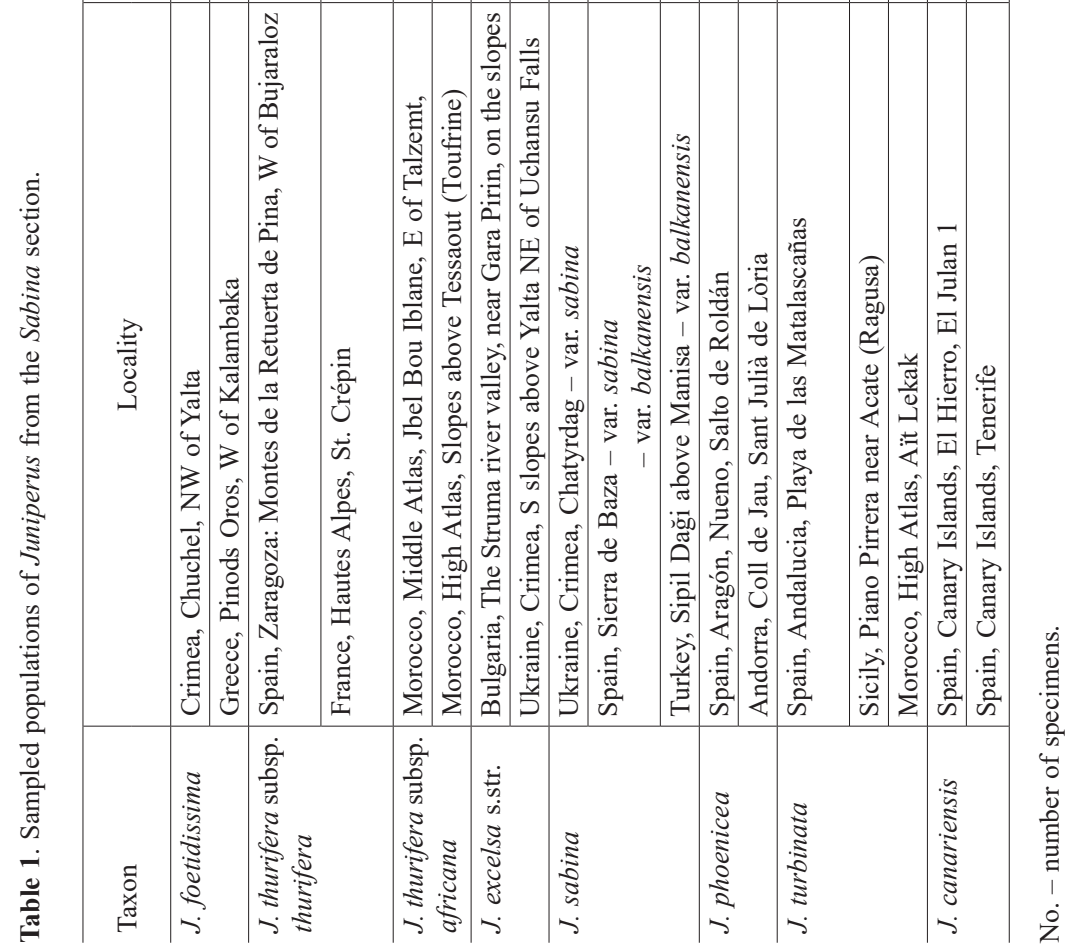




\begin{tabular}{|c|c|c|c|c|}
\hline 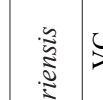 & 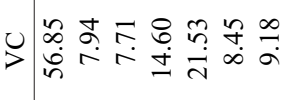 & $\stackrel{\tilde{O}}{\mathrm{I}}$ & $\stackrel{\circ}{a}$ & 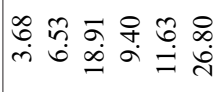 \\
\hline 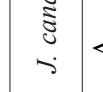 & 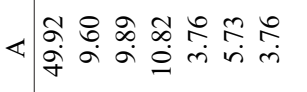 & 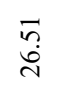 & $\vec{s}$ & 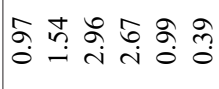 \\
\hline$\cong$ & 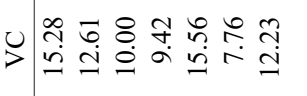 & $\begin{array}{l}\hat{b} \\
\dot{ \pm}\end{array}$ & ๙̃. & 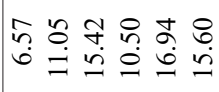 \\
\hline 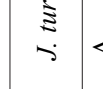 & 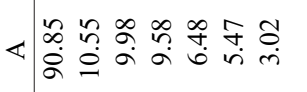 & $\underset{\sim}{\stackrel{N}{*}}$ & $\stackrel{\infty}{\infty}$ & 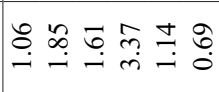 \\
\hline$\stackrel{\Xi}{\dddot{\Xi}}$ & 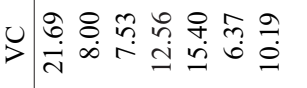 & $\stackrel{\Xi}{=}$ & $\stackrel{\infty}{\stackrel{\leftrightarrow}{=}}$ & 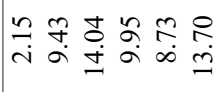 \\
\hline$\sum_{2}^{2}$ & 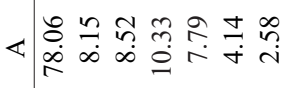 & in & $\stackrel{n}{\circ}$ & 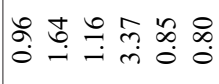 \\
\hline 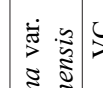 & 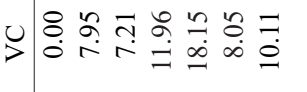 & $\stackrel{i}{\dot{m}}$ & $\stackrel{g}{0}$ & 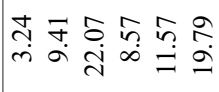 \\
\hline 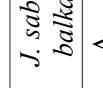 & 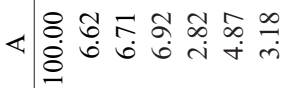 & $\stackrel{\Omega}{\Omega}$ & $\stackrel{\check{\sigma}}{\circ}$ & 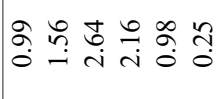 \\
\hline 㟧 & 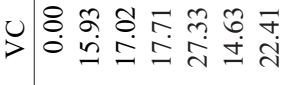 & $\stackrel{\hat{y}}{\stackrel{\varrho}{\Theta}}$ & $\begin{array}{l}n \\
i n\end{array}$ & 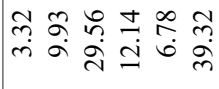 \\
\hline 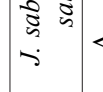 & $\varangle \mid \begin{array}{lll}8 & 0 \\
0 & 0 & 0 \\
0 & 0 & 0\end{array}$ & $\stackrel{g}{g}$ & $\stackrel{\infty}{\infty}$ & 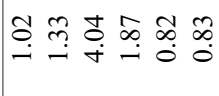 \\
\hline 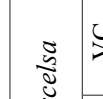 & 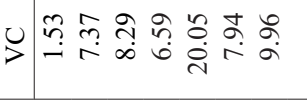 & $\stackrel{\infty}{=}$ & $\stackrel{\infty}{\infty}$ & 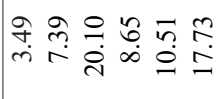 \\
\hline$\stackrel{-}{-}$ & 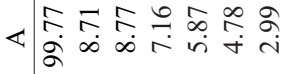 & $\stackrel{n}{\dot{i}}$ & $\stackrel{\Re}{\circ}$ & 엉 \\
\hline 竎 & 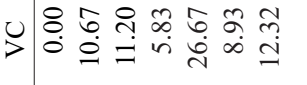 & 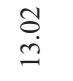 & 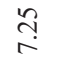 & 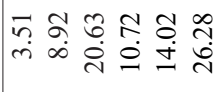 \\
\hline 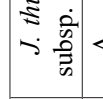 & 《宫竞 & $\stackrel{\stackrel{n}{?}}{=}$ & $\stackrel{\infty}{\infty}$ & 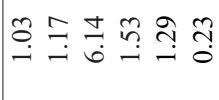 \\
\hline 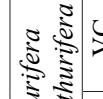 & 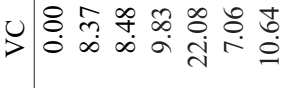 & $\stackrel{\substack{0 \\
\infty}}{=}$ & $\stackrel{?}{i}$ & 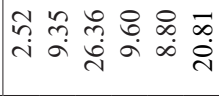 \\
\hline 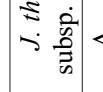 & 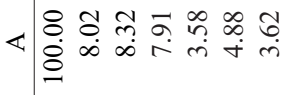 & $\stackrel{8}{9}$ & $\stackrel{\infty}{\infty}$ & 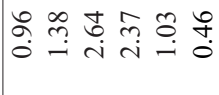 \\
\hline 言 & 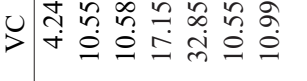 & $\begin{array}{l}\infty \\
\stackrel{\infty}{\mathfrak{I}}\end{array}$ & $\stackrel{\hat{q}}{r}$ & 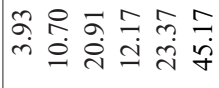 \\
\hline$\stackrel{\vec{s}}{s}$ & 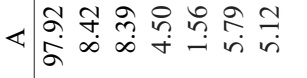 & $\begin{array}{l}\vec{n} \\
\ddot{n}\end{array}$ & $\stackrel{\circ}{=}$ & 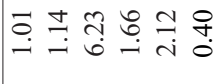 \\
\hline 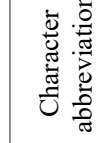 & 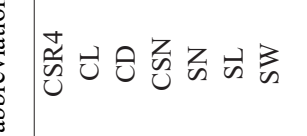 & Z & $\stackrel{\oplus}{\oplus}$ & 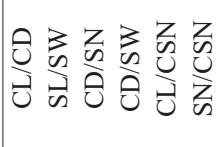 \\
\hline 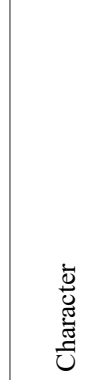 & 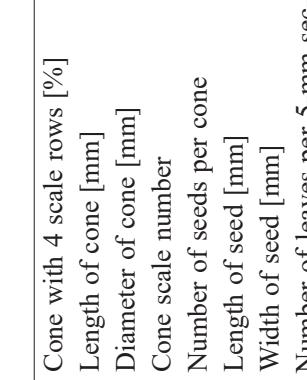 & 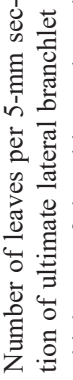 & 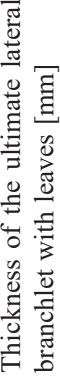 & 象 \\
\hline
\end{tabular}

VC in all compared taxa: $25.0 \%, 22.2 \%$ and $20.9 \%$, respectively. In contrast, the most constant characters in this respect, not including $\mathrm{CL} / \mathrm{CD}$, were the thickness of branchlet (BT) and the length of seed (SL), with VC values: $8.4 \%$ and $8.9 \%$, respectively (Table 2 ).

On average, all studied characters showed significant differences between the compared populations and taxa $(\mathrm{p} \leq 0.01)$. The pairs of taxa are distinguished by seven (J. foetidissima from $J$. thurifera subsp. africana and $J$. sabina var. balkanensis from $J$. thurifera subsp. thurifera) to 15 characters (J. thurifera subsp. africana from $J$. phoenicea) (Table 3), while pairs of populations belonging to the same taxa were distinguished by $1-8$ characters (Table 4). The characters that most often distinguished pairs of taxa were SN and CSN (in 32 and 31 cases, respectively), whereas the characters least frequentlyable to distinguish pairs of taxa were CSR4 and $\mathrm{CL} / \mathrm{CD}$ (in 20 and 21 cases, respectively). In the case of the population within taxa, the most different character was BT, which distinguished seven pairs of populations, while $\mathrm{CSR} 4$ and the ratio $\mathrm{CD} / \mathrm{SW}$ were not distinguished from any pair (Table 4).

Many highly statistically significant correlations were found between the 15 analyzed characters. The most strongly correlated characters are those related to the size of cones $\mathrm{CL}$ and CD (0.94), SN and CD/SW (0.92), SN and SN/CSN (0.91). The weakest correlated characters in relation to the others turned out to be the ratios CL/ $\mathrm{CD}$ and $\mathrm{CL} / \mathrm{CSN}$. To avoid redundancy of characters, nine characters with correlations $(r<0.7)$ were used for multivariate analyses (i.e. CSR4, CD, SL, SW, LN, BT, $\mathrm{CL} / \mathrm{CD}, \mathrm{CL} / \mathrm{CSN}, \mathrm{SN} / \mathrm{CSN}$ ).

The cluster analysis performed on average values of nine characters of nine taxa, showed a close relation of $J$. sabina and $J$. thurifera taxa, of which the African subspecies of $J$. thurifera was the greatest outlier, joining the others in $61 \%$ of the taxonomic distance. The quite close relation between $J$. excelsa and $J$. phoenicea complex, especially to $J$. turbinata (at $47 \%$ of taxonomic distance) was also shown. J. foetidissima turns out to be the most morphologically different, compared to all examined taxa (Fig. 1).

In the discriminant analysis, all nine characters had discriminant significance at a highly significant statistical level $(p<0.01)$. The greatest discriminating power had BT, $\mathrm{CL} / \mathrm{CSN}$ and $\mathrm{CD}$, with partial Wilks' lambda values of $0.20,0.30$ and 0.41 , respectively (Table 5 ). The scatterplot was made in the space between the first two discriminant variables $\left(\mathrm{U}_{1} \& \mathrm{U}_{2}\right)$, with $73.1 \%$ of the total variation. The width of seed (SW) and then two ratios: CL/CSN and SN/ CSN had the greatest influence on $\mathrm{U}_{1}(54.4 \%$ of variation). On the other hand, the character with the greatest impact on $\mathrm{U}_{2}$ (18.7\% of variation) was the thickness of branchlet (BT) (Table 5). Populations on the graph formed four groups. Two of them consisted of the populations of J. foetidissima and $J$. thurifera subs. africana. The third group was made up of $J$. sabina with both varieties and $J$. thurifera subsp. thurifera populations. The last and largest group was made up of the populations of $J$. excelsa, $J$. canariensis, J. turbinata and $J$. phoenicea, which seem to be quite homogeneous 
Table 3. Numbers of characters differing at the statistically significant level $(\mathrm{p} \leq 0.01)$ of nine taxa of Juniperus from the Sabina section using Tukey $T$-test.

\begin{tabular}{|c|c|c|c|c|c|c|c|c|}
\hline Taxa & $\begin{array}{c}\text { Juniperus } \\
\text { foe. }\end{array}$ & $\begin{array}{c}\text { J. thur. } \\
\text { subsp. thur. }\end{array}$ & $\begin{array}{c}\text { J. thur: } \\
\text { subsp. afr. }\end{array}$ & J. exc. & $\begin{array}{c}J . s a b . \text { var. } \\
s a b .\end{array}$ & $\begin{array}{c}\text { J. sab. var. } \\
\text { balk. }\end{array}$ & J. pho. & J. tur. \\
\hline J. thurifera subsp. thurifera & 11 & . & - & . & . & . & . & . \\
\hline J. thurifera subsp. africana & 7 & 12 & . & . & . & . & . & . \\
\hline J. excelsa s.str. & 11 & 11 & 13 & . & . & . & . & . \\
\hline J. sabina var. sabina & 11 & 8 & 10 & 10 & . & . & . & . \\
\hline J. sabina var. balkanensis & 11 & 7 & 12 & 8 & 7 & . & . & . \\
\hline J. phoenicea & 13 & 12 & 15 & 14 & 13 & 11 & . & . \\
\hline J. turbinata & 14 & 13 & 14 & 13 & 13 & 13 & 13 & . \\
\hline J. canariensis & 13 & 9 & 13 & 13 & 13 & 10 & 10 & 11 \\
\hline
\end{tabular}

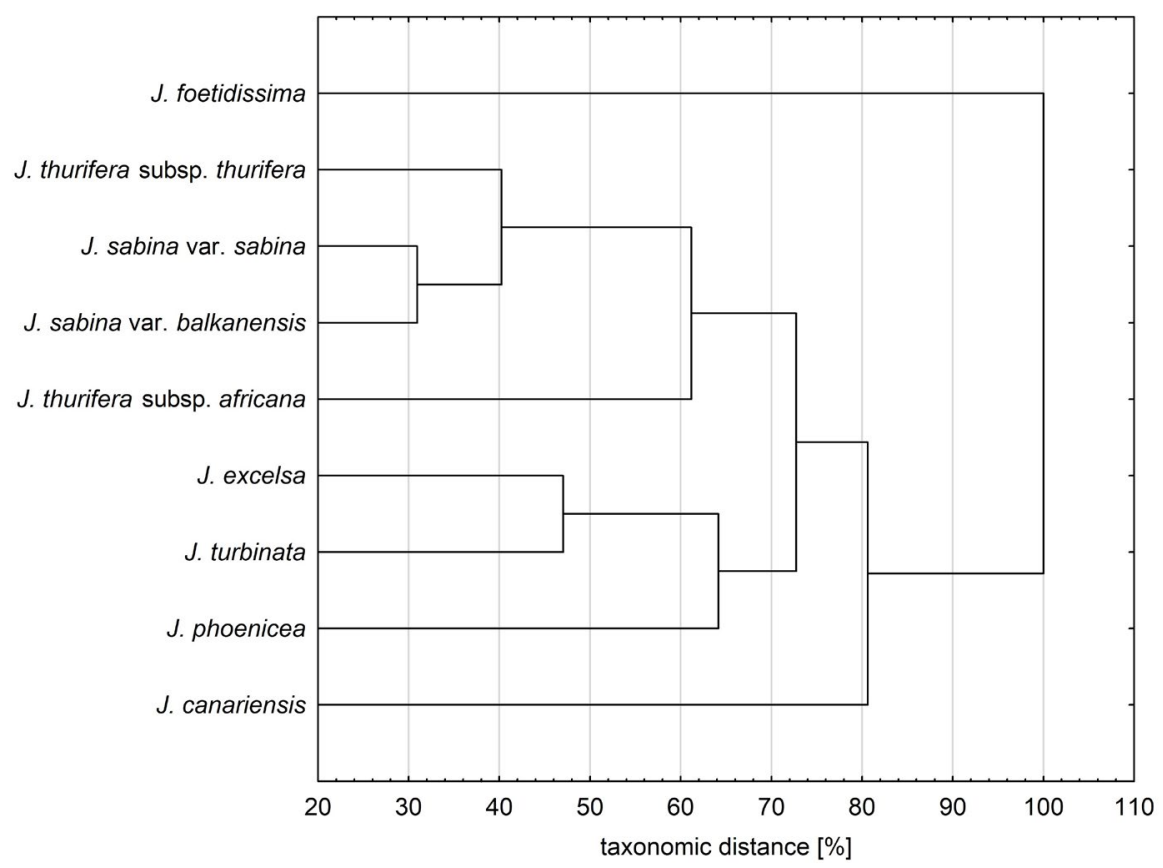

Figure 1. The UPGMA dendrogram, resulting from cluster analysis, made on nine characters of cones, seeds and branchlets with leaves, showing the taxonomic distance between nine Juniperus taxa from the Sabina section (set of nine characters as in Table 5).

Table 4. The list of characters differing at the statistically significant level $(\mathrm{p} \leq 0.01)$ from populations within taxa of Juniperus from the Sabina section using Tukey $T$-test.

\begin{tabular}{lll}
\hline Populations & & Characters \\
\hline FOE_UA & FOE_GR & BT, CD/SN, CL/CSN, SN/CSN \\
THUt_SP & THUt_FR & LN \\
THUa_MA1 & THUa_MA2 & SW, CL/CSN \\
EXC_BG & EXC_UA & CD, BT \\
SABs_UA & SABs_SP & CL, CD, CSN, SL, SW, CD/SN \\
SABb_SP & SABb_TR & CSN \\
SABb_SP & SABs_SP & CD/SN \\
SABs_UA & SABb_SP & CD, CSN \\
SABs_UA & SABb_TR & CL, CD, SL, BT \\
PHO_SP & PHO_AD & CSN, BT \\
TUR_SP & TUR_MO & SN, LN, BT, CL/CD, SN/CSN \\
TUR_SP & TUR_IT & CL, CD, SW, BT, SL/SW, CL/CSN \\
TUR_MO & TUR_IT & CD, SN, SL, SW, LN, CL/CD, SL/SW \\
CAN_SP1 & CAN_SP2 & BT \\
\hline
\end{tabular}

Acronyms of populations as in Table 1, acronyms of character as in Table 2.
Table 5. The result of the discriminant function analysis made on nine characters of cones, seeds and branchlets with leaves from 19 Juniperus populations from the Sabina section.

\begin{tabular}{l|c|c|c|c|c}
\hline Characters & $\begin{array}{c}\text { Partial } \\
\text { Wilk's } \lambda\end{array}$ & $\begin{array}{c}\text { F delete } \\
18.417\end{array}$ & $\mathrm{p}$ & $\begin{array}{c}\mathrm{U}_{1} \\
54.4 \%\end{array}$ & $\begin{array}{c}\mathrm{U}_{2} \\
18.7 \%\end{array}$ \\
\hline CSR4 & 0.52 & 21.53 & 0.00 & 1.48 & 0.01 \\
$\mathrm{CD}$ & 0.41 & 33.47 & 0.00 & 3.14 & 0.01 \\
$\mathrm{SL}$ & 0.67 & 11.50 & 0.00 & 0.88 & 0.76 \\
$\mathrm{SW}$ & 0.52 & 21.75 & 0.00 & 11.01 & 1.28 \\
$\mathrm{LN}$ & 0.50 & 23.27 & 0.00 & 5.91 & 0.00 \\
$\mathrm{BT}$ & 0.20 & 93.17 & 0.00 & 0.62 & 14.10 \\
$\mathrm{CL} / \mathrm{CD}$ & 0.50 & 22.91 & 0.00 & 0.02 & 0.03 \\
$\mathrm{CL} / \mathrm{CSN}$ & 0.30 & 53.12 & 0.00 & 7.38 & 1.34 \\
SN/CSN & 0.49 & 24.05 & 0.00 & 6.88 & 3.08 \\
\hline
\end{tabular}

$\mathrm{p}$ - the statistically significant level; $\mathrm{U}_{1}$ and $\mathrm{U}_{2}$ - the first and second discriminant variables; character abbreviations as in Table 2 . 


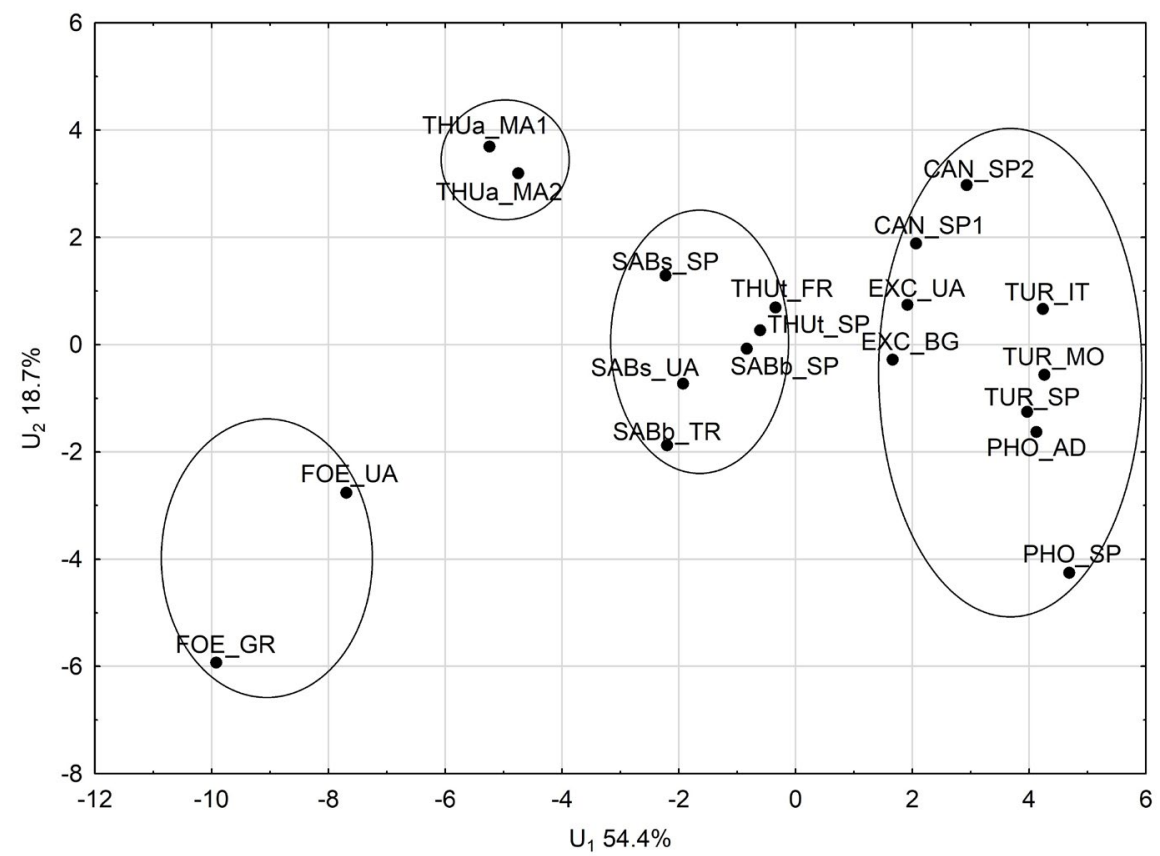

Figure 2. The scatterplot, resulting from discriminant analysis, made for 19 Juniperus populations from the Sabina section, between first two discriminant variables $\left(\mathrm{U}_{1} \& \mathrm{U}_{2}\right)$, based on nine characters of cones, seeds and branchlets with leaves (populations abbreviations as in Table 1; set of nine characters as in Table 5).

in terms of $U_{1}$, but differentiated in terms of $U_{2}(18.7 \%)$, where $J$. canariensis and $J$. phoenicea, especially from Spain (PHO_SP), turned out to be more distant (Fig. 2).

\section{Discussion}

\section{Importance of morphological characters}

All of the morphological characters of seed cones, seeds and shoots turned out to be important in previous studies on individual taxa of Juniperus (Mazur et al. 2004, 2018; Marcysiak et al. 2007; Douaihy et al. 2012; Boratyński et al. 2013) and therefore were also used to analyze the morphological variation in the Sabina section.

Based on the estimated values of the correlation, it was found that seed cones were not only highly statistically significantly correlated with each other and with the characters of the seeds, but also with the number of leaves per shoot (LN). Only the thickness of the final branch of twigs (BT) did not show such correlations with the other measured characters, unlike those described earlier, when analyzing individual species or complexes, where no correlation was shown between the characters of cone and seed or needle and branchlet (Marcysiak et al. 2007; Douaighy et al. 2012; Boratyński et al. 2013; Mazur et al. 2018). The percent of decussate type of cone (CSR4) was highly significantly, negatively correlated with the number of scales (CSN), significantly but less strongly negatively correlated with the number of seeds (SN), while CSN was positively and statistically highly statistically correlated with SN.

In J. sabina and J. thurifera populations, all seed cones were decussate type (CSR4 - 100\%), similarly in one population of $J$. excelsa from the Balkans (EXC_BG), and one of $J$. foetidissima from Greece (FOE_GR). On the other hand, in the $J$. phoenicea complex, ternete cones were observed in each population and in some were the majority. In our comparisons, this happened in one population of $J$. canariensis - CAN SP1 (CSR4 - 46.6\%) (Table 2). From 9.6 to 10.8 scales per cone (CSN), were recorded in the $J$. phoenicea complex, while for the rest of the taxa it was 4.5-7.9 scales. The variation in the number of seeds per cone (SN) was similar because this character depends on the cone scale numbers (Schulz et al. 2003). The largest number of SN characterized J. phoenicea s.str. and $J$. turbinata (7.8 and 6.5, on average, respectively), while $J$. canariensis had a lower value (3.8, on average), but the largest size of seeds (SL and SW) compared to all taxa tested. More seeds were recorded in J. excelsa5.9 seeds per cone, on average, while the remaining taxa ranged from 1.6 to 3.6, on average. A larger number of seeds per cone and different patterns of their arrangement in the seed cone (Lemoine-Sebastian 1967; Schulz et al. 2003), as well as a greater number of scales and a significant share of ternete seed cones, which then underwent a certain simplification with evolution (Schulz et al. 2003), may confirm the suggestion that $J$. phoenicea complex seems to be the most primitive within the genus and that it could have given rise to the others junipers from the Sabina section (Farjon \& Ortiz Garcia 2002, 2005; Schulz et al. 2003; Adams 2014; Mazur et al. 2018). The largest number of scales and the largest share of ternete cones may suggest that $J$. canariensis has the most ancestral character, while the lower number of seeds contradicts this (Mazur et al. 2018). When analyzing vegetative characters, the highest number of leaves per twig (LN) was also noted in the J. phoenicea complex, from 24.3 (J. turbinata) to 26.6 (J. phoenicea), on average, while in the remaining taxa it was 15.6-20.05. It is worth noting that in the case of this character, $J$. excelsa was also characterized by a high value, 
20.05 , on average. Similarly, this species was characterized by a large number of seeds and scales per cone $(5.9$ and 7.2, on average, respectively) (Table 2). The original character of $J$. excelsa can be taken into account for taxa from the Eastern Mediterranean.

\section{Intra- and inter-taxa differences}

The expected result is that more characters differed statistically significantly from taxa than individual populations within them, as demonstrated by numerous previous studies conducted on them (e.g., Boratyński et al. 2013; Mazur et al. 2018). The most common characters discriminating between populations within taxa were the thickness of the branchlet (BT, in 7 cases) and the cone diameter (CD, in 5 cases) (Table 4). Among others, these two characters were shown in earlier studies as significantly differentiating, e.g., within $J$. excelsa s.str. (Mazur et al. 2004), although the studies by Douaihy and co-workers (2012) on much larger material showed the importance of the cone diameter (CD) in differentiation between populations, but $\mathrm{BT}$ only in a few cases. In the present comparison, only the populations within $J$. thurifera, the majority of the population within $J$. sabina (only distinguish between SABs_UA with SABb_TR) and in one case the populations of J. turbinata (TUR_MOU with TUR_IT), the BT character did not distinguish statistically significantly. On the other hand, the CD character significantly distinguished the populations within J. excelsa, J. turbinata and one population of $J$. sabina (SABs_UA). Two analyzed characters did not distinguish the population within taxa: the share of the decussate type of cone (CSR4) and the ratio $\mathrm{CD} / \mathrm{SW}$ (Table 4 ).

The $J$. phoenicea complex was highly statistically significantly distinguished from other taxa by the greatest number of characters, with a few exceptions; e.g., $J$. canariensis from $J$. thurifera subsp. thurifera and from $J$ sabina var. balkanensis have been distinguished only by 9 and 10 characters, respectively. J. thurifera subsp. thurifera differed from subsp. africana by 12 characters, while both subspecies from $J$. sabina var. sabina by 8 and 10 (respectively) (Table 3 ). Only 7 characters distinguished J. sabina var. balkanensis with J. sabina var. sabina and with $J$. thurifera subsp. thurifera, and $J$. thurifera subsp. africana with J. foetidissima. On the genetic level, the similarity between J. sabina var. sabina and $J$. thurifera s.lat. Adams and co-workers (2016) have already observed. Two characters - CSR4 and the ratio $\mathrm{CD} / \mathrm{SW}$, which turned out to be irrelevant in distinguishing the population within taxa, turned out to be very important in distinguishing between taxa. Especially the $\mathrm{CD} / \mathrm{SW}$ made it possible to distinguish statistically significantly almost all taxa and turned out to be one of the most frequently differentiating characters, with the seeds number (SN) (Table 3). SN was also not frequent in distinguishing populations within taxa. It allowed us to distinguish only the populations of $J$. turbinata from Morocco (TUR_MO) from other populations (Table 4).

The two characters that were most significant in distinguishing within taxa, BT and CD, also had an important impact in discriminant analysis made between 19 populations tested (Table 4 and 5). Both the scatterplot and UPGMA dendrogram showed a similarity between $J$. sabina and J. thurifera subs. thurifera, as well as some similarity of $J$. excelsa to the $J$. phoenicea complex and the distinctiveness of $J$. foetidissima (Figs 1-2). Earlier studies, made on the same populations, but concerning selected groups compared here, showed the distinctiveness of $J$. foetidissima from $J$. excelsa s.str. and $J$. thurifera subsp. thurifera (Marcysiak et al. 2007), the distinctiveness of $J$. thurifera subspecies (Boratyński et al. 2013) as well as separateness of $J$. canariensis from other species of the J. phoenicea complex (Mazur et al. 2018). The similarity of $J$. excelsa to $J$. turbinata and other species of the J. phoenicea complex, visible in the scatterplot (Fig. 2), results from the second discriminant variable $\left(\mathrm{U}_{2}\right)$, which depends mainly on the branch thickness (BT), which had similar average values and variation coefficients values in both compared taxa $(0.58-1.00 \mathrm{~mm}, 9.85 \%$ in $J$. excelsa and $0.68-1.00 \mathrm{~mm}, 9.42 \%$ in $J$. turbinata; Table 2). In the dendrogram, $J$. excelsa joins $J$. turbinata at $47 \%$ of the total taxonomic distance (Fig. 1). On the other hand, Tukey's $T$-test showed that these taxa are significantly differentiated by all the examined characters, except for the width of seeds (SW) and the ratio of the cone diameter to the number of seeds $(\mathrm{CD} / \mathrm{SN}$; Table 3$)$.

\section{Geographic variation and migration routes}

The comparison of the average values of the variation coefficients (VC) of morphological characters between individual taxa of Juniperus showed the highest VC in J. foetidissima (15.6\%), J. sabina var. sabina (15.5\%) and $J$. canariensis $(15.0 \%)$. On the other hand, the most permanent ones turned out to be $J$. excelsa and J. sabina var. balkanensis with VC $10.0 \%$ and $10.5 \%$, on average, respectively (Table 2). The high level of variability of the analyzed populations of $J$. foetidissima has already been demonstrated in previous studies (Marcysiak et al. 2007), where the analysis of the same six populations (Table 1) and another four of J. excelsa s.str., J. thurifera subs. thurifera and $J$. foetidissima, based on a similar set of 14 morphological characters, also showed the highest VC of $J$. foetidissima (17.9\%), and lower in $J$. excelsa s.str. and $J$. thurifera subsp. thurifera ( $15.3 \%$ each). These three taxa are assumed to be from the same ancestor (Barbero et al. 1994; Jimenez et al. 2003). However, the demonstrated morphological difference of J. foetidissima (Marcysiak et al. 2007) and its higher VC compared to the others, may indicate earlier divergence or other origin of this species, what has already suggested by Marcysiak and co-workers (2007). This is confirmed by slightly different ecological requirements of $J$. foetidissima, such as occurrence at higher altitudes and smaller areas than the typical $J$. excelsa (Browicz 1982; Boratyński et al. 1992; Didukh 1992; Farjon 2005), It can be assumed that $J$. excelsa s.str. and $J$. thurifera s.lat. are vicariate taxa in two currently isolated areas (Barbero et al. 1994), also $J$. foetidissima and $J$. excelsa can be treated as vicarious species (Jimenez et al. 2003). Studies conducted on the products of terpenoid metabolism have shown similarity of $J$. foetidissima to Central and East Asian 
species and distinctiveness of $J$. excelsa and $J$. thurifera. However, the RAPD research demonstrated a closer relationship between $J$. foetidissima and J. thurifera than between $J$. excelsa, which joined the Central Asian taxa (Adams 1999). This is partially confirmed by the results of the discriminant analysis (Fig. 2), but these conclusions should be verified on a more extensive material (Farjon 2005). All three species are morphologically similar, but despite the sympatricity of the ranges of $J$. excelsa and $J$. foetidissima, which could indicate their close relationship, the morphological similarity of $J$. excelsa s.str. to $J$. thurifera and the distinctiveness of these two species from $J$. foetidissima was demonstrated (Marcysiak et al. 2007).

Further migrations of the $J$. thurifera population from the Iberian Peninsula, in the Tertiary, between the end of the Miocene and the end of the Pliocene, reached Africa. The populations of both continents were in contact before the opening of the Strait of Gibraltar, which is confirmed by the greater genetic similarity of the southern Peninsula populations to African populations (Carrion et al. 2001a; Jiménez et al. 2003). The emergence of the Strait of Gibraltar barrier after glacial periods blocked the flow of genes between Moroccan and European populations, influencing the geographic structure of $J$. thurifera variability (Terrab et al. 2008; Boratyński et al. 2013). Romo \& Boratyński (2007) documented, primarily based on differences in the size of seed cones and the number of seeds inside, two subspecies: J. thurifera subsp. thurifera, found in the Mediterranean part of Europe, and J. thurifera subsp. africana (Maire) Romo \& Boratyński, stat.nov. The distinction between the two subspecies was supported by the previously demonstrated differences in the content of prodelphinidine in the leaves (Gauquelin et al. 1988; Lebreton 1990), the essential oil composition and RAPD (Adams et al. 2003). Other morphological, biochemical and genetic studies conducted on the taxa of $J$. thurifera confirmed the existence of differences, confirming the correctness of distinguishing subspecies (Achak et al. 2008; Terrab et al. 2008; Boratyński et al. 2013). Studies on $J$. thurifera populations showed that this species is tetraploid, making it the only known species that has undergone speciation by genome duplication (polyploidization) (Romo et al. 2013).

Morphological studies of cones, seeds, and shoots of several populations of $J$. excelsa s.str. (Mazur et al. 2004) showed significantly less internal taxon differentiation than similar studies found in J. thurifera (Romo \& Boratyński 2007; Boratyński et al. 2013), although some differences were found between the Crimean and Balkan populations, which was interpreted as the reason of long geographical isolation caused by the origin of the Crimean populations from a refugium other than the Balkan ones (Kornaś \& Medwecka-Kornaś 2002; Yena et al. 2005). The obtained results may also suggest two different ways of their migration, or a different coefficient of morphological divergence in isolated populations, but did not show the reduction of variability of characters in the Crimean populations that might have happened as a result of geographic isolation (Mazur et al. 2004).
Douaihy and co-workers (2012) conducted a morphological versus molecular markers study, but they did not find the expected clear similarities. However, similarities have been shown on a morphological level between the populations of Greece, Turkey, and Crimea, which may be due to a common origin. The Black Sea level during the glaciation was much lower than today, which greatly facilitated the migration of plants along the coast from Anatolia to the Crimea and vice versa (Yena et al. 2005; Douaighy et al. 2012), while the presence of J. excelsa in the eastern Mediterranean during the LGM period (Magyari et al. 2008) indicates possible migrations between the Anatolian and Balkan peninsulas. Other routes of migration to the Crimean and Balkan peninsulas could have caused differences between the populations of $J$. excelsa from these two centers, which is confirmed by previous studies (Mazur et al. 2004). The taxonomy of this complex needs further research.

J. sabina as a typical mountain species is characterized by discontinuous range, but the connection of its parts probably took place many times in the Pleistocene period (Jimenéz et al. 2003; Marcysiak et al. 2007; Boratyński et al. 2013), which may explain the high variability, at least on the morphological level. The explanation of the lower variability of the variety 'balkanensis', which is a tetraploid and has a $J$. thurifera-like chloroplast (Adams et al. 2016; Farhat et al. 2019), requires further research. The authors provided several characters of leaves, cones, and number of seeds that may be useful to distinguish the new variety of $J$. sabina - 'balkanensis' (Adams et al. 2016). In this study, a comparison of four J. sabina populations, including two classified as 'balkanensis', showed a high similarity of all studied populations (Figs 1-2, Table 2), although Tukey's test showed that they were statistically significantly different from one to six characters (Table 4). A recent study of 27 populations of $J$. sabina (including three used in these comparisons, Table 1) also did not confirm the morphological differentiation between these two varieties (unpublished data). 18 morphological characters used in this study, showed high average VC values of characters for both varieties, higher than those for other taxa $(19.9 \%$ in 'sabina' and $19.1 \%$ in 'balkanensis').

The study of 41 populations of $J$. phoenicea complex (including seven used for the present comparison, Table 1; Mazur et al. 2018) showed a higher VC value for $J$. canariensis $(21.5 \%)$, and a lower value for $J$. turbinata $(17.8 \%)$ and $J$. phoenicea (17.4\%). Higher level of phenotypic variability of $J$. phoenicea s.lat., noted in previous research, found in the western part of the range, may support the theory of the European origin of the common ancestor of the complex, confirming its origin from the Iberian Peninsula, where it most likely diverged on J. phoenicea s.str. and J. turbinata (Lebreton \& Rivera 1989; Lebreton \& Perez de Paz 2001; Mao et al. 2010; Dzialuk et al. 2011; Adams et al. 2014 a,b; Mazur et al. 2018). The probable divergence of these two species took place quite early in the history of distinguishing the complex (Adams \& Schwarzbach 2013). Whereas the separation of $J$. canariensis could have happened with the 
formation of the Canary Islands, most likely not earlier than in the Miocene, as a result of colonization from the coast of the Iberian Peninsula (Fernández-Palacios et al. 2011). Thus, in the Canary Islands populations the level of variation should decrease, which, as noted by Mazur and co-workers (2018), did not take place, which the authors explain in two ways: either the Canary Islands are a type of Mediterranean flora enclave in which a high level of morphological variability has been preserved, or a high variability here was a secondary phenomenon that occurred after colonization. The high level of diversity in $J$. canariensis populations did not confirm the tendency to reduce genetic diversity in marginal populations (Hamrick et al. 1992), which was also demonstrated for other species, including junipers, e.g., for $J$. drupacea (Sobierajska et al. 2016).

\section{Acknowledgments}

I would like to thank Professor Adam Boratyński for the countless hours devoted to me during our work with junipers, for being a great promoter of my doctoral dissertation, for support and invaluable substantive help and technical tips at every stage of our cooperation and for the opportunity to work on so many valuable collections of junipers collected by Professor and Professor Krystyna Boratyńska.

\section{References}

Achak, N., Romane, A., Alifriqui, M. \& Adams, R. P. 2008. Effect of the leaf drying and geographic sources on the essential oil composition of Juniperus thurifera L. var. africana Maire from the Tensift - Al Haouz, Marrakech Region. Journal of Essential Oil Research 20: 200-204. https://doi.org/10.1080/10412905.2008.9699990

Adams, R. P. 1999. Systematics of multi-seeded eastern hemisphere $J u$ niperus based on leaf essential oils and RAPD DNA fingerprinting. Biochemical Systematics and Ecology 27: 709-725.

Adams, R. P. 2014. Junipers of the world: The genus Juniperus. $4^{\text {th }}$ ed. Trafford Publishing Co., Bloomington, IN.

Adams, R. P. 2016. Two new cases of chloroplast capture in incongruent topologies in the Juniperus excelsa complex: J. excelsa var. turcomanica comb. nov. and J. excelsa var. seravschanica comb. nov. Phytologia 98: 219-231.

Adams, R. P. \& Schwarzbach, A. E. 2013. Phylogeny of Juniperus using nrDNA and four cpDNA regions. Phytologia 95: 179-187.

Adams, R. P., Pandey, N., Rezzi, S. \& Casanova, J. 2002. Geographic variation in the Random Amplified Polymorphic DNAs (RAPDs) of Juniperus phoenicea, J. p. var. canariensis, J. p. subsp. eu-mediterranea, and J. p. var. turbinata. Biochemical Systematics and Ecology 30(3): 223-229.

Adams, R. P., Mumba, L. E., James, A. S., Pandey, R. N., Gauqueline, T. \& Badri, W. 2003. Geographic variation in the leaf oils and DNA fingerprints (RAPDs) of Juniperus thurifera L. from Morocco and Europe. Journal of Essential Oil Research 15: 148-154. https://doi. org/10.1080/10412905.2003.9712098

Adams, R. P., Nguyen, S. \& Liu, J. 2006a. Geographic Variation in the Leaf Essential Oils of Juniperus sabina L. and J. sabina var. arenaria (E.H. Wilson) Farjon. Journal of Essential Oil Research 18: 497-502. https://doi.org/10.1080/10412905.2006.9699152

Adams, R. P., Nguyen, S. \& Achak, N. 2006b. Geographic variation in Juniperus phoenicea (Cupressaceae) from the Canary Islands, Morocco and Spain based on RAPDs analysis. Phytologia 88: 270-278.

Adams, R. P., Schwarzbach, A. E., Nguyen, S., Morris, J. A. \& Liu, J-Q. 2007. Geographic variation in Juniperus sabina L., J. sabina var. arenaria (E. H. Wilson) Farjon, J. sabina var. davurica (Pall.) Farjon and J. sabina var. mongolensis R. P. Adams. Phytologia 89: $153-166$.

Adams, R. P., Rumeu, B., Nogales, M., \& Fontinha, S. S. 2010. Geographic variation and systematics of Juniperus phoenicea L. from Madeira and the Canary Islands: SNPs from nrDNA and petN-psbM. Phytologia 92: 59-67.

Adams, R. P., Boratyński, A., Arista, M., Schwarzbach, A. E., Leschner, H., Liber, Z., Minissale, P., Mataraci, T. \& Manolis, A. 2013. Analysis of Juniperus phoenicea from throughout its range in the Mediterranean using DNA sequence data from nrDNA and petNpsbM: The case for the recognition of J. turbinata Guss. Phytologia 95: 202-209.

Adams, R. P., Altarejos, J., Arista, M. \& Schwarzbach, A. E. 2014a. Geographic variation in J. phoenicea var. phoenicea from throughout its range: Analysis of nrDNA and the petN-PsbM cp region. Phytologia 96: 247-251.

Adams, R. P., Arista, M., Boratyński, A., Hoauri, H. H., Leschner, H., Liber, Z., Minissale, P., Sciandrello, S. \& Mataraci, T. 2014b. Geographic variation in the leaf essential oil of Juniperus turbinata from throughout its range in the Mediterranean. Phytologia 96: 149-158.

Adams, R. P., Schwarzbach, A. E. \& Tashev, A. N. 2016. Chloroplast capture by a new variety, Juniperus sabina var. balkanensis R. P. Adams and A. N. Tashev, from the Balkan peninsula: A putative stabilized relictual hybrid between $J$. sabina and ancestral J. thurifera. Phytologia 98: 100-111.

Adams, R. P., Boratyński, A., Mataraci, T., Tashev, A. N. \& Schwarzbach, A. E. 2017. Discovery of Juniperus sabina var. balkanensis R. P. Adams and A. N. Tashev in western Turkey (Anatolia). Phytologia 99: 22-31.

Adams, R. P., Boratyński, A., Marcysiak, K., Roma-Marzio, F., Peruzzi, L., Bartolucci, F., Conti, F., Mataraci, T., Schwarzbach, A. E., Tashev, A. N. \& Siljak-Yakovlev, S. 2018a. Discovery of Juniperus sabina var. balkanensis R. P. Adams and A. N. Tashev in Macedonia, Bosnia-Herzegovina, Croatia and Central and Southern Italy and relictual polymorphisms found in nrDNA. Phytologia 100: 117-127.

Adams, R. P., Farhat, P., Shuka, L. \& Silijak-Yakovlev, S. 2018b. Discovery of Juniperus sabina var. balkanensis R. P. Adams and A. N. Tashev in Albania and relictual polymorphisms found in nrDNA. Phytologia 100: 187-194.

Allen, M. B. \& Armstrong, H. A. 2008. Arabia-Eurasia collision and the forcing of mid Cenozoic global cooling. Palaeogeography, Palaeoclimatology, Palaeoecology 265(1-2): 52-58. https://doi. org/10.1016/j.palaeo.2008.04.021

Arrigoni, P. V. 2012. Miscellaneous notes about some taxa of the Italian flora. Webbia 67: 37-46. https://doi.org/10.1080/00837792.2012.1 0670907

Axelrod, D. 1975. Evolution and biogeography of Madrean-Tethyan sclerophyll vegetation. Annals of the Missouri Botanical Garden 62: 280-334. https://doi.org/10.2307/2395199

Barbero, M., Lebreton, Ph. \& Quézel, P. 1994. Sur les affinités biosystématiques et phytoécologiques de Juniperus thurifera L. et de Juniperus excelsa Bieb. Ecologia Mediterranea 20: 21-37.

Bennet, K. D., Tzedakis, P. C. \& Willis, K. J. 1991. Quaternary refugia of north European trees. Journal of Biogeography 18: 103-115. https://doi.org/10.2307/2845248

Bocquet, G., Widler, B. \& Kiefer, H. 1978. The Messinian Model A new outlook for the floristics and systematics of the Mediterranean area. Candollea 33(2): 269-287.

Boratyński, A., Browicz, K. \& Zieliński, J. 1992. Chorology of trees and shrubs in Greece. Institute of Dendrology of Polish Academy of Sciences, Kórnik.

Boratyński, A., Lewandowski, A., Boratyńska, K., Montserrat, J. M. \& Romo, A. 2009. High level of genetic differentiation of Juniperus phoenicea (Cupressaceae) in the Mediterranean region: Geographic implications. Plant Systematics and Evolution 277: 163-172. https:// doi.org/10.1007/s00606-008-0122-z 
Boratyński, A., Jasińska, A. K., Marcysiak, K., Mazur, M., Romo, A. M., Boratyńska, K., Sobierajska, K. \& Iszkuło, G. 2013. Morphological differentiation supports the genetic pattern of the geographic structure of Juniperus thurifera (Cupressaceae). Plant Systematics and Evolution 299: 773-784. https://doi.org/10.1007/s00606-0130760-7

Boratyński, A., Wachowiak, W., Dering, M., Boratyńska, K., Sękiewicz, K., Sobierajska, K., Jasińska, A. K., Klimo, M., Montserrat, J. M., Romo, A., Ok, T. \& Didukh, Y. 2014. The biogeography and genetic relationships of Juniperus oxycedrus and related taxa from the Mediterranean and Macaronesian regions. Botanical Journal of the Linnean Society 174: 637-653. https://doi.org/10.1111/boj.12147

Browicz, K. 1982. Chorology of trees and shrubs in South-West Asia and adjacent regions. Vol. 1. Polish Academy of Science, Institute of Dendrology, Poznań - Kórnik. Państwowe Wydawnictwo Naukowe, Poznań

Carrión, J. S., Andrade, A., Bennett, K. D., Navarro, C. \& Munuera, M. 2001a. Crossing forest thresholds: inertia and collapse in a Holocene sequence from south-central Spain. Holocene 11: 635-653. https:// doi.org/10.1191/09596830195672

Carrión, J. S., Munuera, M., Dupré, M. \& Andrade, A. 2001b. Abrupt vegetation changes in the Segura mountains of southern Spain. Journal of Ecology 89: 783-797. https://doi.org/10.1046/j.00220477.2001.00601.x

Carrión, J. S., Yll, E. I., Walker, M. J., Legaz, A. J., Chain, C. \& López, A. 2003. Glacial refugia of temperate, Mediterranean and Ibero-North African flora in south-eastern Spain: new evidence from cave pollen at two Neanderthal sites. Global Ecology and Biogeography 12(2): 119-129. https://doi.org/10.1046/j.1466-822X.2003.00013.x

Carrión, J. S., Yll, E. I., Willis, K. J. \& Sanchez, P. 2004. Holocene forest history of the eastern plateaux in the Segura Mountains (Murcia, southeastern Spain). Review of Palaeobotany and Palynology 132: 219-236. https://doi.org/10.1016/j.revpalbo.2004.07.002

Carrión, J. S., Fernández, S., González-Sampériz, P., Gil-Romera, G., Badal, E., Carrión-Marco, Y., López-Merino, L., López-Sáez, J. A., Fierro, E. \& Burjachs, F. 2010. Expected trends and surprises in the Lateglacial and Holocene vegetation history of the Iberian Peninsula and Balearic Islands. Review of Palaeobotany and Palynology 162: 458-475. https://doi.org/10.1016/j.revpalbo.2009.12.007

Cattell, R. B. 1943. The description of personality: Basic characters resolved into clusters. Journal of Abnormal and Social Psychology 38: 476-506. https://doi.org/10.1037/h0054116

Charco, J. 2001. Gúla de los árboles y arbustos del norte de Africa. Agencia Española de Cooperación Internacional, Madrid.

Didukh, Y. P. 1992. Rastitelnyj pokrov Gornogo Kryma. Naukova Dumka, Kiev.

Douaihy, B., Sobierajska, K., Jasińska, A. K., Boratyńska, K., Ok, T., Romo, A., Machon, N., Didukh, Y., Dagher Kharrat, M. B. \& Boratyński, A. 2012. Morphological versus molecular markers to describe variability in Juniperus excelsa subsp. excelsa (Cupressaceae). Annals of Botany Plants 013: 1-14. https://doi.org/10.1093/ aobpla/pls013:pls013

Dzialuk, A., Mazur, M., Boratyńska, K., Montserrat, J. M., Romo \& A., Boratyński, A. 2011. Population genetic structure of Juniperus phoenicea (Cupressaceae) in the western Mediterranean Basin: Gradient of diversity on a broad geographical scale. Annals of Forest Science 68: 1341-1350. https://doi.org/10.1080/14772000.2016.1257518

Farhat, P., Siljak-Yakovlev, S., Adams, R. P., Dagher Kharrat, M. B. \& Robert, T. 2019. Genome size variation and polyploidy in the geographical range of Juniperus sabina L. (Cupressaceae). Botany Letters 166(2): 10. https://doi.org/10.1080/23818107.2019.1613262

Farhat, P., Takvorian, N., Avramidou, M., Garraud, L., Adams, R. P., Siljak-Yakovlev, S., Dagher Kharrat, M. B. \& Robert, T. 2020. First evidence for allotriploid hybrids between Juniperus thurifera and $J$. sabina in a sympatric area in the French Alps. Annals of Forest Sciences 77: 93. https://doi.org/10.1007/s13595-020-00969-7

Farjon, A. 2005. A monograph of Cupressaceae and Sciadopitys. Royal Botanic Gardens, Kew.
Farjon, A. \& Ortiz Garcia, S. 2002. Towards the minimal conifer cone: Ontogeny and trends in Cupressus, Juniperus and Microbiota (Cupressaceae s.str.). Botanisches Jahrbücher für Systematic 124: 129-147.

Farjon, A. \& Ortiz Garcia, S. 2005. The early development of ovuliferous cones of Cupressaceae s.1. - a survey of the genera. In: Farjon, A. (ed.), A Monograph of Cupressaceae and Sciadopitys. pp. 27-46. Royal Botanic Gardens, Kew.

Favre, E., François, L., Fluteau, F., Cheddadi, R., Thévenod, L. \& Suc, J-P. 2007. Messinian vegetation maps of the Mediterranean region using models and interpolated pollen data. Geobios 40: 433-443. https://doi.org/10.1016/j.geobios.2006.12.002

Ferńandez-Palacios, J. M., Otto, R., Delgado, J. D., Arévalo, J. R., Naranjo, A., Artiles, F. G., Morici, C. \& Barone, R. 2008. Los bosques termofilos de Canarias. Proyecto IFE04/NAT/ES/000064. Excmo. Cabildo Insular de Tenerife, Santa Cruz de Tenerife.

Ferńandez-Palacios, J. M., de Nascimento, L., Otto, R., Delgado, J. D., Garćia-del-Rey, E., Arévalo, J. R. \& Whittaker, R. J. 2011. A reconstruction of Palaeo-Macaronesia, with particular reference to the long-term biogeography of the Atlantic island laurel forests. Journal of Biogeography 38: 226-246. https://doi.org/10.1111/j.13652699.2010.02427.x

Gauquelin, T., Hassani, M. I. \& Lebreton, P. 1988. Le Genévrier thurifère, Juniperus thurifera L. (Cupressacees): analyse biométrique et biochimique; propositions systématiques. Ecologia Meditteranea 14: $31-42$.

Hamrick, J. L., Godt, M. J. W. \& Sherman-Broyles, S. L. 1992. Factors influencing levels of genetic diversity in woody plant species. New Forests 6: 95-124.

Hewitt, G. M. 1996. Some genetic consequences of ice ages, and their role in divergence and speciation. Biological Journal of the Linnean Society 58: 247-276. https://doi.org/10.1111/j.1095-8312.1996. tb01434.x

Hewitt, G. M. 1999. Post-glacial re-colonization of European biota. Biological Journal of the Linnean Society 68: 87-112. https://doi. org/10.1006/bij1.1999.0332

Hewitt, G. M. 2004. Genetic consequences of climatic oscillations in the Quaternary. Philosophical Transactions of the Royal Society B: Biological Sciences 359: 183-195. https://doi.org/10.1098/ rstb. 2003.1388

Hojjati F., Zarre, S. \& Assadi, M. 2009. Isoenzyme diversity and cryptic speciation in Juniperus excelsa (Cupressaceae) complex in Iran. Biochemical Systematics and Ecology 37: 193-200. https://doi. org/10.1016/j.bse.2009.03.002

Hojjati, F., Sereshti, H. \& Hojjati, M. 2019. Leaf essential oils and their application in systematics of Juniperus excelsa complex in Iran. Biochemical Systematics and Ecology 84: 29-34. https://doi. org/10.1016/j.bse.2019.03.004

Ivanov, D., Utescher, T., Mosbrugger, V., Syabryaj, S., Djordjević-Milutinović, D. \& Molchanoff, S. 2011. Miocene vegetation and climate dynamics in Eastern and Central Paratethys (Southeastern Europe). Palaeogeography, Palaeoclimatology, Palaeoecology 304: 262-275. https://doi.org/10.1016/j.palaeo.2010.07.006

Jalas, J. \& Suominen, J. (eds) 1973. Atlas Florae Europaeae. Vol. 2. The Committee for Mapping the Flora of Europe and Societas Biologica Fennica Vanamo, Helsinki.

Jiménez, J. F., Werner, O., Sanchez-Gomez, P., Fernández, S. \& Guerra, J. 2003. Genetic variations and migration pathway of Juniperus thurifera L. (Cupressaceae) in the western Mediterranean region. Israel Journal of Plant Sciences 51: 11-22. https://doi.org/10.1560/ ABR5-A6MP-5XEG-V0WF

Jiménez, J. F., Sánchez-Gómez, P., Cánovas, J. L., Hensen, I. \& Aouissat, M. 2017. Influence of natural habitat fragmentation on the genetic structure of Canarian populations of Juniperus turbinata. Silva Fennica 51(1678): 1-14. https://doi.org/10.14214/sf.1678

Kornaś, J. \& Medwecka-Kornaś, A. 2002. Geografia roślin. Wyd. 2. Wydawnictwo Naukowe PWN, Warszawa. 
Kovar-Eder, J., Kvaček, Z., Martinetto, E. \& Roiron, P. 2006. Late Miocene to Early Pliocene vegetation of southern Europe (7-4 $\mathrm{Ma})$ as reflected in the megafossil plant record. Palaeogeography, Paleoclimatology, Palaeoecology 238: 321-339. https://doi. org/10.1016/j.palaeo.2006.03.031

Kvaček, Z. 2002. A new juniper from the Paleogene of Central Europe. Feddes Repertorium 113: 492-502. https://doi.org/10.1002/ fedr.200290001

Lebreton, P. 1990. La chimiotaxonomie des Gymnospermes. Bulletin de la Société Botanique de France. Lettres Botaniques 137(1): 35-46. https://doi.org/10.1080/01811797.1990.10824864

Lebreton, P. \& Pérez de Paz, P. L. 2001. Définition du Genévrier de Phénicie (Juniperus aggr. phoenicea), reconsidéré à ses limites biogéographiques: Méditerranée orientale (Crète et Chypre) et Atlantique (Iles Canaries). Bulletin mensuel de la Société linnéenne de Lyon 70: 73-92.

Lebreton, P. \& Rivera, D. 1989. Analyse du taxon Juniperus phoenicea $\mathrm{L}$. sur des bases biochimiques et biométriques. Naturalia Monspeliensia, Serie botanique 53: 17-41.

Lebreton, P. \& Thivend, S. 1981. Sur une sous-espèce du Genévrier de Phénicie Juniperus phoenicea L., définie à partir de critères biochimiques. Naturalia Monspeliensia, Serie botanique 47: 1-12.

Lemoine-Sébastian, C. 1967. L'inflorescence femelle des Juniperaie: Ontogenèse, structure, phylogenèse. Travaux du Laboratoire Forestier de Toulouse 7: 1-455.

Magyari, E. K., Chapman, J. C., Gaydarska, B., Marinova, E., Deli, T., Huntley, J.P., Allen, J. R. M. \& Huntley, B. 2008. The 'oriental' component of the Balkan flora: evidence of presence on the Thracian Plain during the Weichselian late-glacial. Journal of Biogeography 35: 865-883. https://doi.org/10.1016/j.quascirev.2012.01.006

Mao, K., Hao, G., Liu, J., Adams, R. P. \& Milne, R. I. 2010. Diversification and biogeography of Juniperus (Cupressaceae): Variable diversification rates and multiple intercontinental dispersals. New Phytologist 185: 332-342. https://doi.org/10.1111/j.14698137.2010.03351.x

Mao, K., Ruhsam, M., Ma, Y., Graham, S. W., Liu, J., Thomas, Ph., Milne, R. I. \& Hollingsworth, P. M. 2019. A transcriptome-based resolution for a key taxonomic controversy in Cupressaceae. Annals of Botany 123: 153-167. https://doi.org/10.1093/aob/mcy175

Marcysiak, K., Mazur, M., Romo, A., Montserrat, J. M., Didukh, Y., Boratyńska, K., Jasińska, A., Kosiński, P. \& Boratyński, A. 2007. Numerical taxonomy of Juniperus thurifera, J. excelsa and J. foetidissima (Cupressaceae) based on morphological characters. Botanical Journal of the Linnean Society 155: 483-495. https://doi. org/10.1111/j.1095-8339.2007.00730.x

Mazur, M., Boratyńska, K., Marcysiak, K., Gómez, D., Tomaszewski, D., Didukh, Y., Boratyński, A. 2003. Morphological variability of Juniperus phoenicea (Cupressaceae) from three distant localities on Iberian Peninsula. Acta Societatis Botanicorum Poloniae 72: 71-78.

Mazur, M., Boratyńska, K., Marcysiak, K., Didukh, Y., Romo, A., Kosiński, P. \& Boratyński, A. 2004. Low level of inter-populational differentiation in Juniperus excelsa M. Bieb. (Cupressaceae). Dendrobiology 52: 39-46.

Mazur, M., Marcysiak, K., Boratyński, A., Boratyńska, K., Romo, A., Montserrat, J. M., Kosiński, P. 2005. Morphological variation of Juniperus thurifera L. (Cupressaceae) from four populations in South-Western Europe. In: Prus-Głowacki, W., Pawlaczyk, E. M. (eds), Variability and evolution-new perspectives, vol. 72, pp. 399-409. Ser. Biologia. Adam Mickiewicz University, Poznań.

Mazur, M., Klajbor, K., Kielich, M., Sowińska, M., Romo, A., Montserrat, J. M. \& Boratyński, A. 2010. Intra-specific differentiation of Juniperus phoenicea in the western Mediterranean region revealed in morphological multivariate analysis. Dendrobiology 63: 21-31.

Mazur, M., Minissale, P., Sciandrello, S. \& Boratyński, A. 2016. Morphological and ecological comparison of populations of Juniperus turbinata Guss. and J. phoenicea L. from the Mediterranean region. Plant Biosystems 150: 313-322. https://doi.org/10.1080/11263504. 2014.994579
Mazur, M., Zielińska, M., Boratyńska, K., Romo, A., Salvà-Catarineu, M., Marcysiak, K. \& Boratyński, A. 2018. Taxonomic and geographic differentiation of Juniperus phoenicea agg. based on cone, seed, and needle characteristics. Systematics and Biodiversity 16: 469-483. https://doi.org/10.1080/14772000.2018.1439120

McLachlan, G. J. 2004. Discriminant Analysis and Statistical Pattern Recognition. John Wiley \& Sons, New York.

Meloni, M., Perini, D., Filigheddu, R. \& Binelli, G. 2006. Genetic variation in five Mediterranean populations of Juniperus phoenicea as revealed by inter-simple sequence repeat (ISSR) markers. Annals of Botany 97: 299-304. https://doi.org/10.1093/aob/mcj024

Pearson, K. 1900. On the criterion that a given system of deviations from the probable in the case of a correlated system of variables is such that it can be reasonably supposed to have arisen from random sampling. Philosophical Magazine 5(50): 157-175.

Petit, R. J., Aguinagalde, I., Beaulieu, J. L., Bittkau, C., Brewer, S., Cheddadi, R., Ennos, R., Fineschi, S., Grivet, D., Lascoux, M., Mohanty, A., Müller-Starc, G., Demdesure-Musch, B., Palmé, A., Martín, J. P., Rendell, S. \& Vendramin, G. G. 2003. Glacial refugia: hotspots but not melting pots of genetic diversity. Science 300: 1563-1565. https://doi.org/10.1126/science.1083264

Pinna, M. S., Grilloa, O., Mattanaa, E., Cañadasad, E. M. \& Bacchetta, G. L. 2014. Inter- and intraspecific morphometric variability in Juniperus L. seeds (Cupressaceae). Systematics and Biodiversity 12: 211-223. https://doi.org/10.1080/14772000.2014.904827

Popov, S. V., Shcherba, I. G., Ilyina, L. B., Nevesskaya, L. A., Paramonova, N. P., Khondrakian, S. O. \& Magyar, I. 2006. Late Miocene to Pliocene palaeogeography of the Paratethys and its relation to the Mediterranean. Palaeogeography, Palaeoclimatology, Palaeoecology 238: 91-106. https://doi.org/10.1016/j.palaeo.2006.03.020

Quezel, P. \& Pesson, P. 1980. Biogeographie et ecologie des conifers sur le pourtour mediterraneen. Gauthier-Villars, Paris. Actualites d'ecologie forestiere 205-255.

Romo, A. \& Boratyński, A. 2005. Chorology of Juniperus thurifera (Cupressaceae) in Morocco. Dendrobiology 54: 41-50.

Romo, A. \& Boratyński, A. 2007. Nomenclatural note on Juniperus thurifera subsp. africana (Cupressaceae). Annales Botanici Fennici 44: $72-75$.

Romo, A. M. \& Salvà-Catarineu, M. 2013. Phytodiversity of the remnants of Canarian endemic juniper woodlands on El Hierro, Canary Islands / La phytodiversité dans les rémanents de la forêt endémique de genévrier d'El Hierro, îles Canaries. Ecologia Mediterranea 39: 191-199.

Romo, A., Hidalgo, O., Boratyński, A., Sobierajska, K., Jasińska, A. K., Vallès, J. \& Garnatje, T. 2013. Genome size and ploidy levels in highly fragmented habitats: the case of western Mediterranean Juniperus (Cupressaceae) with special emphasis on J. thurifera L. Tree Genetics \& Genomes 9: 587-599. https://doi.org/10.1007/ s11295-012-0581-9

Romo, A., Mazur, M., Salva-Catarineu, M. \& Boratyński, A. 2019 A re-evaluated taxon: Genetic values and morphological characters support the recognition of the Canary Island juniper of the phoenicea group at a specific level. Phytotaxa 406(1): 64-70. https:// doi.org/10.11646/phytotaxa.406.1.3

Salvà-Cotarineu, M., Romo, A., Mazur, M., Zielinska, M., Minissale, P., Dönmez, A. A., Boratyńska, K. \& Boratyński, A. 2021. Past, present and future geographic range of the relict Mediterranean and Macaronesian Juniperus phoenicea complex. Ecology and Evolution 11: 5075-5095. https://doi.org/10.1002/ece3.7395

Sánchez-Gómez, P., Jiménez, J. F., Cánovas, J. L., Vera, J. B., Hensen, I. \& Aouissat, M. 2018. Genetic structure and phylogeography of Juniperus phoenicea complex throughout Mediterranean and Macaronesian regions: different stories in one. Annals of Forest Science 75: 75. https://doi.org/10.1007/s13595-018-0741-7

Sanguin, H., Mathaux, C., Guibal, F., Prin, Y., Mandin, J-P., Gauquelin, T. \& Duponnois, R. 2016. Ecology of vertical life in harsh environments: The case of mycorrhizal symbiosis with secular cliff 
climbing trees (Juniperus phoenicea L.). Journal of Arid Environments 134: 132-135. https://doi.org/10.1016/j.jaridenv.2016.07.008

Schulz, C., Jagel, A. \& Stutzel, T. 2003. Cone morphology in Juniperus in the light of cone evolution in Cupressaceae s.1. Flora 198: 161-177. https://doi.org/10.1078/0367-2530-00088

Sobierajska, K., Boratyńska, K., Jasińska, A., Dering, M., Ok, T., Douaihy, B., Dagher-Kharrat, M. B., Romo, A. \& Boratyński, A. 2016. Effect of the Aegean Sea barrier between Europe and Asia on differentiation in Juniperus drupacea (Cupressaceae). Botanical Journal of the Linnean Society 180: 365-385. https://doi. org/10.1111/boj.12377

Sokal, R. R. \& Rohlf, T. J. 2003. Biometry: The principles and practice of statistics in biological research, Eight printing. Freeman W. H. and Comp, San Francisco.

Terrab, A., Schoenswetter, P., Talavera, S., Vela, E. \& Stuessy, T. F. 2008. Range-wide phylogeography of Juniperus thurifera L., a presumptive keystone species of western Mediterranean vegetation during cold stages of the Pleistocene. Molecular Phylogenetics and Evolution 48: 94-102. https://doi.org/10.1016/j.ympev.2008.03.018

Tzedakis, P. C. 2004. The Balkans as prime glacial refugial territory of European temperate trees. In: Griffiths, H. I., Kryštufek, B. \& Reed, J. M. (eds), Balkan biodiversity, pp. 49-68. Kluwer Academic Press, Dortrecht/Boston/London.

Verdú, M., Davila, P., Garcia-Fayos, P., Flores-Hernandez, N. \& Valiente-Banuet, A. 2003. 'Convergent' characters of mediterranean woody plants belong to pre-mediterranean lineages. Biological Journal of the Linnean Society 78: 415-427. https://doi.org/10.1046/ j.1095-8312.2003.00160.x
Wen, J. \& Ickert-Bond, S. M. 2009. Evolution of the Madrean-Tethyan disjunctions and the North and South American amphitropical disjunctions in plants. Journal of Systematics and Evolution 47(5): 331-348. https://doi.org/10.1111/j.1759-6831.2009.00054.x

Wen, J., Nie, Z-L. \& Ickert-Bond, S. M. 2016. Intercontinental disjunctions between eastern Asia and western North America in vascular plants highlight the biogeographic importance of the Bering land bridge from late Cretaceous to Neogene. Journal of Systematics and Evolution 54(5): 469-490. https://doi.org/10.1111/jse.12222

Willis, J. K. \& McElwain, J. C. 2002. The evolution of plants. Oxford University Press, Oxford, New York.

Yena, An., Yena, Al. \& Yena, V. 2005. 'Stankewicz pine' in Crimea: some new taxonomical, chorological and paleolandscape considerations. Dendrobiology 53: 63-69.

Zając, M. \& Zając, A. 2009. The geographical elements of native flora of Poland. Laboratory of Computer Chorology, Institute of Botany, Jagiellonian University, Kraków.

Zar, J. H. 1999. Biostatistical analysis. $4^{\text {th }}$ ed. Prentice-Hall, New Jersey.

Zohary, M. 1973. Geobotanic foundation of the Middle East. Gustav Fischer Verlag and Sweets and Zeitlinger, Stuttgart and Amsterdam. 